\title{
A moda, a arte e suas manifestações disruptivas
}

A revista dObra[s] chega ao número 25 e, no presente texto, além de apresentarmos o conteúdo que integra a edição, também comunicamos algumas novidades.

Desde o início deste ano, o periódico está presente em mais um indexador, o MIAR, da Universidade de Barcelona. A indexação nessa plataforma foi uma iniciativa da professora Alessandra Vaccari (luav-Veneza), que organizou, ao lado da professora Ivana Simili (Uem), o dossiê veiculado no nosso número 24. Deixamos, portanto, o nosso agradecimento a Alessandra pela iniciativa, que colabora a visibilidade internacional da revista.

Outra novidade importante é que, a partir do número 26 , os textos enviados à revista devem seguir um novo modelo, baseado em dois documentos da Associação Brasileira de Normas Técnicas (ABNT): a NBR 6022, versão de maio de 2018, que trata da formatação de artigos em publicação periódica e científica, e a NBR 6023, sobre elaboração de referências bibliográficas, em sua atualização de novembro de 2018.

Este novo modelo, em suas versões para artigos, resenhas, traduções e entrevistas, já está disponível no site da dObra[s], no menu "Sobre" > "Políticas". Para elaborar o trabalho dentro das normas da revista, basta fazer download do documento e substituir o conteúdo. Um resumo das normas também é apresentado na seção "Sobre" > "Políticas" > "Normas para publicação na revista dObra[s]", com versões em português e inglês.

Estas modificações têm por objetivo facilitar a normalização dos trabalhos submetidos à revista, e também padronizar a apresentação de maneira a atender critérios de importantes bases indexadoras.

Informamos ainda que, a partir de 2019, a Nominata dos pareceristas será publicada apenas no último número do ano, a ser lançado em dezembro. Desta maneira, visamos prosseguir divulgando os nomes de todos os professores e pesquisadores doutores que colaboraram com a revista emitindo pareceres e, ao mesmo tempo, dificultando a associação entre artigos e avaliadores. 
Apresentadas as novidades, vamos ao dossiê A moda e suas manifestações disruptivas: dor, rebeldia e não-conformismo. Organizado pelas pesquisadoras Juliana Schmitt (pós-doutoranda no Programa de Pós-Graduação em Artes, Cultura e Linguagens da UFJF) e Maíra Zimmermann (professora da Faap), o dossiê conta com oito artigos produzidos por pesquisadores que atuam no Brasil, Espanha, França e Inglaterra. Com trabaIhos escritos em português, inglês, francês e espanhol, o dossiê colabora para reforçar o projeto de internacionalização da revista, cujos textos agora podem ser lidos não apenas por falantes da língua portuguesa.

Ao mesmo tempo, o dossiê traz, na seção Costuras - cujo objetivo é disponibilizar traduções de textos já publicados em outras línguas ou versões ampliadas ou revisadas de publicações "clássicas" -, dois artigos escritos originalmente em francês e que, agora, estão ao alcance de quem não domina o idioma. Os textos de Catherine Lamoüe e Alex Moulinier, que tratam respectivamente dos usos da maquiagem pelos homens e da polêmica produção de designers de moda contemporâneos, integram originalmente o catálogo da exposição Tenue correcte exigée! Quand le vetêment fait scandale, sob direção de Denis Bruna, em cartaz de 1 de dezembro de 2016 a 23 abril de 2017 no Museu de Artes Decorativas em Paris. 0 Museu gentilmente cedeu os direitos para a tradução e publicação dos textos e deixamos aqui os agradecimentos pela cessão.

0 dossiê apresenta ainda uma resenha do recém-lançado Minha fama de $m a u$, cinebiografia do cantor e compositor Erasmo Carlos, com foco no início de sua carreira e, em especial, de sua atuação no período da Jovem Guarda. E, também, uma entrevista com o jornalista Daniel Flores, sobre as origens do punk na Argentina.

Na seção de fluxo contínuo, esta edição 25 publica trabalhos que manifestam a transdisciplinaridade do campo científico da moda. Maria Adircila Starling Sobreira apresenta uma pesquisa bibliométrica sobre o estudo de têxteis no Brasil, com interessantes resultados acerca das áreas que mais têm dado atenção a este tema. Francisco Nunes dos Reis e Laura Novaes Andrade, por sua vez, tratam das contribuições da psicologia social para os estudos da moda. Articulando este campo à filosofia e à literatura, Ana Carolina Acom, Joana Bosak e Denise Moraes defendem a produtividade da obra de Thomas Carlyle, Sartor Resartus, para a compreensão de fenômenos da moda. Ainda na seara da participação da moda na constituição das identidades, Marta Sorelia Felix de Castro, José Clerton de Oliveira Martins e Karla Patrícia Martins Ferreira estabelecem uma associação entre o punk e slow fashion como movimentos de resistência. 
Manifestações disruptivas relacionadas à moda também podem ser vistas nas duas resenhas de exposição que completam esta edição. Apesar de não integrarem o dossiê, é possivel situá-las neste tema, pois tais exposições reuniram retrospectivas de obras de artistas mulheres e negras: Maria Auxiliadora, cuja produção foi apresentada no Museu de Arte de São Paulo Assis Chateaubriand (Masp), entre março e junho de 2018, e Rosana Paulino, que teve seu trabalho exibido na Pinacoteca do Estado de São Paulo entre dezembro de 2018 e março de 2019. As autoras das resenhas são, respectivamente, Hanayrá Negreiros e Aimê Okasaki. Se os espaços consagrados das artes vêm se abrindo para a exibição para esse tipo de produção artística, a revista dObra[s], ao publicar tais resenhas, tem por objetivo ampliar o alcance e o questionamento em torno do trabalho das artistas, levando tais imagens e problemáticas para além do espaço museológico e da cidade de São Paulo - onde ocorreram as mostras.

As exposições das quais tratam as resenhas, que deram visibilidade à produção artística de duas mulheres negras que ocorreram em instituições de com notoriedade internacional, podem ser consideradas também formas de ruptura no sistema tradicional do mundo das artes, no qual, como vem denunciando desde a década de 1980 o coletivo de artistas mulheres Guerrilla Girls', os acervos e as exposições de obras produzidas por mulheres ainda são minoria. Não à toa, as resenhas foram também produzidas por pesquisadoras.

A apreensão dos sentidos sobre a moda se completa, na dObra[s], pelas imagens que acompanham a produção verbal. Nesta edição, ilustrando a capa e o miolo da revista, temos diversas fotografias de registros de desfiles da Casa de Criadores edição Inverno 2019 - evento que vem se firmando como um espaço para marcas nacionais inovadoras (e disruptivas). As fotografias são de Marcelo Soubhia e Zé Takahashi da Agência Fotosite, que cedeu os direitos de imagem, e para quem deixamos nosso muito obrigada. Registramos ainda que a escolha das imagens foi feita pelas organizadoras do dossiê, que buscaram fotografias que dialogassem com os temas abordados. Somos gratas, portanto, às organizadoras pelo empenho em selecionar imagens e obter seus direitos de uso para esta edição da dObra[s].

Boa leitura!

Adriana Tulio Baggio e Maria Claudia Bonadio 